\title{
Comércio internacional, especialização produtiva e competitividade: uma decomposição para o crescimento das exportações brasileiras entre 1995 e 2014
}

\author{
Felipe Amaral (Doutorando em economia IE-UFRJ) \\ Fabio Freitas (Professor do IE-UFRJ) \\ Marta Castilho (Professora do IE-UFRJ)
}

\begin{abstract}
Resumo: Entre 1995 e 2014, as exportações brasileiras cresceram a uma taxa superior ao crescimento das exportações mundiais. Além desse crescimento acelerado, também houve uma mudança na composição da pauta exportadora com forte crescimento do peso dos produtos básicos em detrimento dos manufaturados. O objetivo deste artigo é investigar os determinantes do crescimento recente das exportações brasileiras e explicar o crescimento acelerado das vendas externas de produtos primários e das manufaturas baseadas em recursos naturais. Essa investigação será realizada por meio de uma metodologia que decompõe o crescimento das exportações em quatro componentes. O primeiro está associado ao crescimento da competitividade do país nos diferentes produtos exportados. O segundo capta o dinamismo dos mercados para os produtos exportados. O terceiro e o quarto captam, respectivamente, a elasticidade-renda do comércio internacional e o impacto do crescimento da renda mundial. Os resultados indicam que, entre 1995 e 2011, os efeitos renda mundial e elasticidade-renda do comércio foram os que mais contribuíram para o crescimento das exportações brasileiras, embora a contribuição dos outros fatores tenha sido positiva na maioria dos casos. Ou seja, o bom desempenho das exportações brasileiras teria sido determinado tanto por fatores de ordem macroeconômica quanto setoriais. O aumento da elasticidade-renda do comércio internacional e da renda mundial impulsionou o crescimento das exportações brasileiras que, por sua vez, foram beneficiadas pelo aumento dos preços e da demanda mundial por mercadorias em que o país já era especializado. Isto intensificou a participação relativa de produtos menos sofisticados na pauta brasileira e aprofundou a especialização comercial do país nos produtos primários e nas manufaturas baseadas em recursos naturais.
\end{abstract}

Palavras-chave: Exportações brasileiras; Comércio internacional; Competitividade; Especialização comercial e produtiva.

\author{
ÁREA 1 - INDÚSTRIA E COMPETITIVIDADE. \\ Área 1.4 - Padrões de especialização produtiva e desenvolvimento.
}




\section{Introdução}

Nos escritos da CEPAL, a dinâmica centro-periferia retratava a estrutura que determinava um padrão assimétrico de inserção internacional: os países da periferia produziam bens com demanda internacional pouco dinâmica e importavam bens com demanda doméstica em rápida expansão. Nos países do centro, a elasticidade-renda das exportações seria maior que um devido à sua especialização na produção de bens industrializados. Já na periferia, a estrutura produtiva seria marcada pela especialização na produção de bens primários e/ou de baixa sofisticação tecnológica, cuja demanda cresce lentamente quando comparada aos produtos industriais exportados pelos países do centro (PREBISCH, 1949).

$\mathrm{O}$ fato de as economias em desenvolvimento exportarem bens com baixa elasticidade-renda da demanda e importarem bens com alta elasticidade-renda faz com que seja impossível para esses países obter, ao mesmo tempo, altas taxas de crescimento e equilíbrio no balanço de pagamentos. Os esforços desses países para eliminar os déficits externos acabam causando recessão ou inflação, o que acaba limitando o crescimento de qualquer maneira. Nesse contexto, as exportações se configuram como uma variável central e estratégica para o crescimento e relaxamento da restrição externa devido ao duplo papel que elas desempenham. Ao mesmo tempo em que são fonte autônoma de demanda efetiva, as exportações também são, em última instância, a fonte de divisas internacionais de um país (MEDEIROS E SERRANO, 2001).

Entre 1995 e 2011, as exportações brasileiras foram fortemente beneficiadas pela expansão do comércio internacional e cresceram, em média, $11 \%$ ao ano ${ }^{1}$. Esse crescimento foi superior ao crescimento das exportações mundiais, que cresceram pouco mais de $8 \%$ anualmente. Entretanto, a partir da desaceleração no crescimento do comércio internacional desencadeada pela crise de 2008, as exportações brasileiras perderam força e, inclusive, começaram a diminuir a partir de 2011 . Ao longo desse processo ocorreram alterações significativas na estrutura da pauta de exportação brasileira, sendo uma delas a mudança na composição dos produtos exportados. Os bens básicos ganharam peso nas exportações totais e se tornaram a principal categoria exportada, ao mesmo tempo em que, como contrapartida, as manufaturas não baseadas em recursos naturais perderam espaço. Esse fenômeno foi denominado na literatura como especialização regressiva (COUTINHO, 1987).

Entretanto, essa especialização em mercadorias menos sofisticadas não foi um fenômeno ocorrido apenas no Brasil. Com o aumento no preço das commodities e o crescente apetite chinês por essas mercadorias as exportações desses produtos ganharam participação nas exportações mundiais também. Todavia, mesmo sendo uma tendência mundial, no Brasil esse movimento na direção de mercadorias menos elaboradas e intensivas em recursos naturais foi mais intenso do que o observado no mundo.

O objetivo deste artigo é investigar os determinantes do crescimento das exportações brasileiras entre 1995 e 2014. Trata-se, portanto, de identificar as fontes do crescimento recente das exportações e explicar o crescimento acelerado das vendas externas de produtos primários e das manufaturas baseadas em recursos naturais. O método proposto decompõe o crescimento das exportações de um país em quatro componentes. O primeiro está associado ao aumento da competitividade do país nos diferentes produtos. O segundo capta o dinamismo diferenciado dos diversos grupos de produtos e sua variação na participação no comércio mundial. $O$ terceiro e o quarto representam, respectivamente, a elasticidade-renda do comércio internacional e o impacto do crescimento da renda mundial.

Para isso, o presente trabalho está dividido, além desta introdução e da conclusão, em mais três seções. Na próxima seção demonstraremos a importância das exportações para o crescimento econômico, chamando a atenção para o seu duplo papel de prover tanto demanda efetiva quanto as divisas internacionais necessárias para o relaxamento da restrição externa. Nesta mesma seção ainda discutiremos sobre a relação existente entre a estrutura produtiva, o crescimento das exportações e o

\footnotetext{
${ }^{1}$ Segundo dados do COMTRADE - Nações Unidas (http://comtrade.un.org/).
} 
relaxamento da restrição externa. Na Seção 2 apresentaremos a metodologia proposta para decompor o crescimento das exportações de um país e identificar suas fontes. Finalmente, na terceira seção apresentaremos os principais resultados.

\section{1) Exportações, restrição externa e estrutura produtiva}

\section{1 - A restrição externa e o duplo papel das exportações}

Num contexto de crescimento liderado pela demanda as exportações podem ser mais ou menos importantes dependendo de uma série de características estruturais de cada país. Entretanto, seu papel no relaxamento da restrição externa é central e estratégico para todos os países (MEDEIROS \& SERRANO, 2001; p.106). Dado o duplo papel exercido pelas exportações, é primordial entender a distinção entre o papel que estas desempenham como componente da demanda efetiva e sua função de prover divisas internacionais e relaxar a restrição externa.

A restrição externa, ou do balanço de pagamentos, é definida como a escassez de divisas para o pagamento das importações. Como as obrigações internacionais devem ser pagas em uma moeda de referência, os países que não emitem essa moeda ficam limitados pela sua capacidade de gerar divisas. Assim, essa escassez é proveniente da diferença entre a moeda emitida internamente e a moeda usada como meio de pagamento internacional. Nesse caso, o país que emite a moeda internacional não sofre uma restrição externa (MEDEIROS \& SERRANO, 1999). Para contornar essa restrição, existem duas maneiras de se obter divisas internacionais: exportações ou fluxos de capitais. Enquanto as exportações se constituem numa entrada direta de divisas sem contrapartidas, os fluxos de capitais dependem da disponibilidade de crédito e dos custos deste passivo.

A relação entre o Balanço de Pagamentos (BP) e a determinação do produto é oriunda da hipótese de que as importações são induzidas pelo nível de atividade da economia. Com o crescimento do produto, cresce o volume de importações e a necessidade de se obter divisas internacionais. Neste processo, o produto de longo prazo fica limitado pela capacidade de gerar as divisas necessárias para se pagar pelas importações. Os modelos de crescimento com restrição no balanço de pagamentos àla Thirlwall (1979) estabeleceram uma relação onde o crescimento do produto compatível com o equilíbrio nas contas externas é igual à razão entre as elasticidades-renda de exportação e importação multiplicada pelo crescimento da renda do resto do mundo ou, de maneira mais simples, a razão entre o crescimento das exportações e a elasticidade-renda de importação:

$$
g_{B P}=(\varepsilon / \pi) g_{R M}=x / \pi
$$

Essa equação ficou conhecida na literatura como "Lei de Thirlwall" e nela $g_{B P}$ representa o crescimento do produto que equilibra o balanço de pagamentos, $\varepsilon$ e $\pi$ representam, respectivamente, as elasticidades-renda de exportação e importação, $g_{R M}$ representa o crescimento do resto do mundo e $x$ o crescimento das exportações, ou seja, o crescimento do produto compatível com o equilíbrio no BP é uma função direta do crescimento das exportações de um país ${ }^{2,3}$

\footnotetext{
${ }^{2}$ McCombie e Roberts (2002) argumentam que existe uma diferença crucial entre o crescimento das exportações e dos outros componentes da demanda, na medida em que apenas as exportações geram moeda internacional para se pagar pelas importações. Uma vez que isso é levado em consideração, o crescimento das exportações se revela como o principal componente para o crescimento da demanda. Para os autores, isso se deve ao fato de que o crescimento das exportações permite o crescimento dos outros gastos através do relaxamento da restrição externa.

${ }^{3}$ Interessante notar que esse resultado se mantém mesmo na presença de fluxos de capitais. A explicação para isso está no fato de que, no curto prazo um país pode endividar-se para relaxar a restrição externa, mas no longo prazo esse endividamento deve ser pago de alguma maneira e a as exportações continuam sendo a única fonte de divisas que não gera contrapartidas. Além disso, McCombie e Roberts (2002) apresentam estimações da "Lei de Thirlwall" em que a inclusão dos fluxos de capitais alterou pouco ou quase nada os resultados obtidos com o modelo padrão. Em suas palavras: "even if there is a sustainable current account deficit, the quantitative impact on the equilibrium growth rate is so small that [...] Thirlwall's law, will give a very good approximation to the balance-of-payments-constrained growth rate" (p. 96).
} 
(McCOMBIE \& THIRLWALL, 1994). Nessa literatura ${ }^{4}$ o equilíbrio no BP é tido como um centro de gravitação ou um objetivo de política econômica, de maneira que o crescimento observado do produto seja sempre igual àquele que equilibra as contas externas (BHERING \& SERRANO, 2014).

Por outro lado, se o crescimento da produção é determinado pelo princípio da demanda efetiva, a taxa de crescimento do produto que equilibra o balanço de pagamentos é apenas um limite superior e o produto determinado pela demanda efetiva só não pode ser maior que aquele por longos períodos, caso contrário essa economia esbarraria na restrição externa. Isso acontece porque a condição de equilíbrio no BP é assimétrica. A situação onde um país incorra recorrentemente em déficits no balanço de pagamentos não pode ser sustentada por muito tempo, uma vez que o país em questão estaria perdendo continuamente suas reservas internacionais. Já a situação oposta, onde o país obtém superávits recorrentes no balanço de pagamentos, pode ser mantida por longos períodos, causando apenas um acúmulo crescente de reservas internacionais (MEDEIROS \& SERRANO, 2001). Assim, não há nenhum mecanismo de mercado que justifique a igualdade entre o produto observado e àquele associado ao equilíbrio das contas externas. Não existe também nenhum outro mecanismo que assegure o equilíbrio da balança comercial no longo prazo (BHERING \& SERRANO). Em outras palavras, a taxa de crescimento do produto determinada pelos modelos de crescimento àla Thirlwall (1979) representa apenas o limite para o qual a economia pode crescer sem esbarrar na restrição externa. Com isso, abre-se a possibilidade de que alguns países estejam operando sistematicamente abaixo dessa restrição e, nesse caso, o balanço de pagamentos não precisaria estar sempre equilibrado, uma vez que um país poderia se manter superavitário de forma recorrente.

Para Bhering e Serrano (2014), este resultado implica dizer que os modelos de crescimento com restrição externa não deveriam ter como objetivo se constituir como uma alternativa aos modelos de crescimento liderados pela demanda. Ao invés disso, eles deveriam explicar a restrição ao crescimento proveniente das contas externas. Se assumirmos que o produto de longo prazo determinado pelo princípio da demanda efetiva é diferente do nível de produto que equilibra as contas externas, então abrimos espaço para a explicação de diferentes trajetórias de crescimento baseadas em diferentes regimes de acumulação. Dessa maneira, o crescimento não será sempre liderado pelas exportações, podendo haver diferentes regimes de crescimento associados a diferentes composições da demanda agregada ${ }^{5}$. Entretanto, é importante ressaltar que, mesmo num contexto onde o crescimento não é liderado pelas exportações, estas não perdem sua importância, uma vez que continuam a desempenhar sua função de prover divisas internacionais para se pagar pelas importações e, assim, relaxar a restrição externa.

\section{2 - Competitividade e estrutura produtiva}

Como vimos na última subseção a literatura representada pela "Lei de Thirlwall" identifica nas exportações o principal motor do crescimento econômico e isso tem levado a um interesse crescente sobre os determinantes das elasticidades de comércio. Refletindo fatores pelo lado da oferta que são associados à possibilidade de sucesso no comércio internacional, as elasticidadesrenda da demanda (tanto de exportações quanto de importações) incorporam elementos da competitividade que não são completamente capturados pelos preços dos bens (ROMERO ET AL., 2011). Nesse sentido, uma das principais diferenças entre essa abordagem e os modelos de crescimento neoclássicos àla Solow é o papel da competição via preços. Na primeira abordagem seu papel é muito reduzido e a concorrência se dá através da diferenciação de produtos. Isso é captado (imperfeitamente) pelas diferentes elasticidades-renda das exportações e importações dos países. Tendo em vista que não se observam variações expressivas nos fluxos de comércio devido a pequenas mudanças nos preços, as diferenças entre as elasticidades-renda de exportação e

\footnotetext{
${ }^{4}$ Ver Kaldor (1978[1971]), McCombie\& Thirlwall (1994), McCombie\& Roberts (2002) e Thirlwall (2005), por exemplo.

${ }^{5}$ Para mais informações sobre os diferentes regimes de crescimento, ver Freitas e Dweck (2013).
} 
importação refletiriam as disparidades entre as estruturas produtivas dos países, bem como as de suas pautas exportadoras e importadoras (CIMOLI \& CORREA, 2002; CIMOLI ET AL., 2010; FAGERBERG ET AL.; 2007; JAYME JR. \& RESENDE, 2009; OCAMPO, 2009; PALMA, 2009; ROMERO ET AL., 2011).

O sucesso de um país nos mercados mundiais está envolvido com a diferenciação e inovação de produtos, ou seja, os países devem se especializar em desenvolver produtos para os quais a demanda mundial está crescendo rapidamente. A mera redução dos preços através da compressão dos custos (como os salários reais, por exemplo) ou de desvalorizações cambiais tem pouco ou nenhum efeito sobre o crescimento de longo prazo das exportações. McCombie e Roberts (2002) apontam vários estudos que, ao estimar a elasticidade-preço das exportações, encontraram coeficientes estatisticamente não significativos, baixos ou com o sinal trocado. Fagerberg et al. (2007) também demonstram que os efeitos da competitividade preço são muito reduzidos quando comparados com outros aspectos da concorrência internacional.

Esses outros aspectos são tratados na literatura como competitividade não-preço. McCombie e Thirlwall (1994) definem esses fatores como sendo aqueles que afetam a escolha dos consumidores como, por exemplo, qualidade e diferenciação dos produtos, tempo de entrega, tamanho e eficácia da rede de distribuição, disponibilidade de crédito, entre outros. Esses fatores seriam captados pelas elasticidades-renda de comércio, tanto de exportação quanto de importação.

Já quanto à razão entre as elasticidades, Cimoli et al. (2010) sugerem que seja uma função do padrão de especialização produtiva. Mais especificamente, essa razão vai depender da participação que setores com uma alta eficiência keynesiana e schumpeteriana (ver definição a seguir) têm na produção total e nas exportações. Os setores com maior capacidade de criar externalidades tecnológicas, com maior oportunidade de aprendizado tecnológico e com taxas elevadas de inovação possuem eficiência schumpeteriana. Por sua vez, setores onde a demanda (interna e externa) cresce de maneira acentuada, servindo de estímulo para a expansão da produção e do investimento, possuem eficiência keynesiana ${ }^{6}$ (DOSI ET AL., 1990). Ou seja, as elasticidadesrenda de comércio são função da capacidade que um país tem de produzir bens mais intensivos em tecnologia e/ou com uma demanda crescente no comércio internacional.

A razão entre as elasticidades refletiria, assim, o padrão de especialização produtiva de cada país. Esta taxa deve ser considerada como o resultado das características da estrutura econômica do país e seus esforços para alcançar a fronteira tecnológica (CIMOLI ET AL., 2010). O conceito de estrutura produtiva engloba a composição das atividades produtivas, o padrão de especialização associado ao comércio internacional e as capacidades tecnológicas da economia. Isto inclui o nível educacional da força de trabalho, a estrutura de propriedade dos fatores de produção, a natureza e o desenvolvimento das instituições do estado e o grau de desenvolvimento e restrições sob as quais certos mercados operam ${ }^{7}$ (OCAMPO, 2009, p. 7). Essa estrutura, por sua vez, indicaria o grau de desenvolvimento tecnológico de um país, sendo os periféricos especializados na produção de produtos primários ou com uma baixa sofisticação tecnológica.

Ao longo do tempo, com as mudanças tecnológicas e as inovações de produto, a composição setorial da demanda internacional está sempre mudando. Dessa forma, manter uma taxa de crescimento das exportações acima do crescimento mundial requer um processo contínuo de rápida mudança estrutural na direção de setores com alta eficiência keynesiana, i.é, setores que estejam ganhando participação no mercado internacional.

A relação entre os padrões de especialização produtiva e o perfil exportador dos países apresenta implicações cruciais em relação ao crescimento das exportações. Isso se dá na medida em que os diversos setores e mercadorias estão associados a diferentes elasticidades-renda da demanda por exportações, diferentes graus de retornos de escala e diferentes possibilidades de inovação tecnológica e aprendizado. Estruturas produtivas diversas têm diferentes implicações para o

\footnotetext{
${ }^{6}$ De fato, há uma grande sobreposição de setores possuindo ambas as eficiências, mas nem sempre essas características andam juntas. $\mathrm{O}$ fato de que alguns bens experimentam um aumento maior em sua demanda internacional do que outros nem sempre coincide com as diferentes intensidades tecnológicas dos setores (CIMOLI ET AL, 2010).

${ }^{7}$ A falta de certos segmentos do mercado financeiro ou o desemprego em massa, por exemplo.
} 
crescimento das exportações, uma vez que desempenham diferentes capacidades e possibilidades de inovação e produção. Segundo Lall (2000):

Technology-intensive structures offer better prospects for future growth because their products tend to grow faster in trade: they tend to be highly income elastic, create new demand and substitute faster for older products. [...] They also have greater potential for further learning because they offer more scope for applying new scientific knowledge. They have larger spillover effects in terms of creating new skills and generic knowledge that can be used in other activities. Simple technologies, by contrast, tend to have slower growing markets, more limited learning potential, smaller scope for technological upgrading and less spillover to other activities. They are also more vulnerable to easy entry by lower wage competitors, substitution by technical change and market shifts (p. 339-340).

Em resumo, a relação entre as elasticidades-renda de exportação e importação está diretamente ligada à estrutura produtiva de um país. Quanto menos desenvolvida for a estrutura produtiva de uma economia, menor será a geração e difusão do progresso técnico e, dessa forma, menor a sua competitividade não-preço. Também será menor a sua capacidade de produzir bens que estejam na fronteira tecnológica ou que estejam ganhando participação no comércio internacional. Assim, a estrutura produtiva tende a ser pouco diversificada, bem como seu coeficiente de importação também tende a ser maior que o de exportação, principalmente nas fases expansivas do ciclo econômico.

\section{2) Metodologias para decomposição do crescimento das exportações}

As análises de decomposição do crescimento das exportações buscam separar e quantificar diferentes efeitos para entender como cada um deles contribui para a variação do valor exportado por um país e/ou região. Nesse sentido, a análise de Constant Market Share (CMS) é frequentemente empregada em estudos sobre o desempenho das exportações. Nesse tipo de análise, o crescimento das exportações é atribuído a fatores estruturais e de competitividade ${ }^{8}$. Entretanto, neste trabalho utilizaremos uma metodologia alternativa para decompor o crescimento das exportações. A decomposição proposta vai além do método CMS ao dar um melhor tratamento aos efeitos competitividade e crescimento do comércio, o que justifica sua adoção no presente trabalho ${ }^{9}$.

Para começar vamos decompor o valor exportado $\left(X_{i}^{j}\right)$ do i-ésimo produto pelo país $\mathrm{j}$ da seguinte forma:

$$
X_{i}^{j}=\frac{X_{i}^{j}}{X_{i}^{W}} \frac{X_{i}^{W}}{X^{W}} \frac{X^{W}}{Y^{W}} Y^{W}
$$

onde $X_{i}^{W}$ representa o valor das exportações mundiais da i-ésima mercadoria, $X^{W}$ representa o valor total das exportações mundiais e $Y^{W}$ representa a renda mundial. Com essa decomposição, o valor exportado do i-ésimo produto pelo país j é dividido em quatro componentes. O primeiro indica a

\footnotetext{
${ }^{8}$ No núcleo do modelo está a hipótese de que a parcela de mercado (market-share) de um país nas exportações mundiais permanece a mesma ao longo do tempo. A diferença entre o crescimento das exportações derivada desse market-share constante e a performance observada é atribuída ao efeito de mudanças na competitividade do país, sendo que a variação das exportações é dividida em outros três efeitos: crescimento do comércio mundial, composição da pauta de exportação e distribuição dos mercados de destino. As exportações de um país podem não crescer tanto quanto as exportações mundiais por três motivos: (1) as exportações podem estar concentradas em mercadorias cuja demanda cresce relativamente menos do que outras (efeito composição da pauta); (2) os principais destinos para essas exportações podem estar crescendo menos que o resto do mundo (efeito distribuição dos mercados de destino); e (3) o país em questão pode não ter sido capaz de manter sua competitividade frente a outros competidores (efeito competitividade). Para mais informações sobre o método CMS, ver Leamer \& Stern (1970) ou Richardson (1971b). Há também diversos estudos aplicando essa metodologia para o crescimento recente das exportações brasileiras, como Lima, Lélis e Cunha (2015), Pereira e Souza (2011) e Pinheiro e Bonelli (2007).

${ }^{9}$ Foge ao escopo deste trabalho uma análise detalhada sobre os métodos de decomposição do crescimento das exportações. Para uma apresentação das principais críticas ao método CMS e uma discussão mais extensa sobre a decomposição proposta ver Amaral (2016).
} 
parcela de mercado do país nas exportações mundiais desse produto $\left(X_{i}^{j} / X_{i}^{W}\right)$. O segundo é constituído pela participação das exportações mundiais dessa mercadoria nas exportações mundiais totais $\left(X_{i}^{W} / X^{W}\right)$. O terceiro indica a razão entre o comércio internacional (representado pelas exportações) e o produto mundial, ou seja, a participação do comércio no PIB do mundo $\left(X^{W} / Y^{W}\right)$. Por fim, o último componente indica o nível do produto mundial $\left(Y^{W}\right)$. Para simplificar a notação, sejam $C_{i}^{j}=X_{i} / X_{i}^{W} ; D_{i}=X_{i}^{W} / X^{W}$ e $T=X^{W} / Y^{W}$, de maneira que a Equação (1) assuma a seguinte forma:

$$
X_{i}^{j}=C_{i}^{j} D_{i} T Y^{W}
$$

Com isso, as exportações do i-ésimo produto pelo país $\mathrm{j}$ ficam sendo iguais à multiplicação dos quatro componentes: (i) o market-share do país j nesse mercado $\left(C_{i}^{j}\right)$; (ii) a parcela desse produto nas exportações mundiais $\left(D_{i}\right)$; (iii) a participação do comércio internacional sobre a renda mundial (T); e (iv) o PIB mundial ( $\left.Y^{W}\right)$. A equação anterior pode ser apresentada em taxas de crescimento da seguinte forma:

$$
\begin{gathered}
x_{i}^{j}=c_{i}^{j}+d_{i}+t+y_{w}+r \\
r=c_{i}^{j} d_{i}+c_{i}^{j} t+c_{i}^{j} y^{W}+d_{i} t+d_{i} y^{W}+t y^{W}+c_{i}^{j} d_{i} t+c_{i}^{j} d_{i} y^{W}+c_{i}^{j} t y^{W}+d_{i} t y^{W}+c_{i}^{j} d_{i} t y^{W}
\end{gathered}
$$

Aqui, a taxa de crescimento das variáveis é representada por letras minúsculas. Pela Equação (2), temos que o crescimento das exportações de cada produto é igual à soma do crescimento dos quatro componentes citados mais um termo de interação $(r)$. Se o primeiro termo $\left(c_{i}^{j}\right)$ é positivo, quer dizer que o país em questão está ganhando parcela de mercado, ou seja, ganhando participação nas exportações mundiais desse produto e ficando mais competitivo. $\mathrm{O}$ segundo componente $\left(d_{i}\right)$ capta o dinamismo do i-ésimo produto no mercado mundial. Se as exportações desse produto crescem mais que a média das exportações totais, o produto em questão é dinâmico e sua procura cresce de maneira mais acentuada, o que aumenta sua participação no comércio internacional. Esse termo indica quais produtos possuem eficiência keynesiana como discutido na seção anterior. $\mathrm{O}$ terceiro fator $(t)$ indica quanto o comércio internacional cresceu mais ou menos que a renda mundial, ou seja, esse termo representa a elasticidade-renda do comércio internacional. Já o quarto termo $\left(y^{W}\right)$ indica o impacto que o crescimento da renda mundial teve sobre o crescimento das exportações do país j. Por fim, assim como na análise de Constant Market Share, a aplicação da decomposição implica no uso de dados com tempo discreto, o que faz com que o crescimento das exportações da iésima mercadoria também seja determinado pela interação entre o crescimento de cada componente. Para facilitar a exposição, agregamos todos esses termos de interação em $r$. Neste trabalho assume-se que os termos de interação não possuem significado econômico específico e podem ser considerados apenas como aspectos dinâmicos da evolução das exportações.

Podemos agora agregar as exportações de todos os produtos para encontrar o crescimento total das exportações do país j. Fazendo isso chegamos à seguinte equação, que relaciona o crescimento total das exportações do país j $\left(x^{j}\right)$ com os componentes da decomposição do crescimento do i-ésimo produto:

$$
\begin{gathered}
x^{j}=\sum_{i} \lambda_{i} c_{i}^{j}+\sum_{i} \lambda_{i} d_{i}+t+y_{w}+r \\
r=\sum_{i} \lambda_{i}\left(\begin{array}{c}
c_{i}^{j} d_{i}+c_{i}^{j} t+c_{i}^{j} y^{W}+d_{i} t+d_{i} y^{W}+c_{i}^{j} d_{i} t \\
+c_{i}^{j} d_{i} y^{W}+c_{i}^{j} t y^{W}+d_{i} t y^{W}+c_{i}^{j} d_{i} t y^{W}
\end{array}\right)+t y^{W}
\end{gathered}
$$


onde $\lambda_{i}$ representa a participação da i-ésima mercadoria na pauta de exportação no período inicial ${ }^{10}$. $\mathrm{O}$ crescimento das exportações de um país é decomposto então na soma de cinco componentes ou efeitos. O primeiro efeito está associado ao crescimento do market-share do país nas diferentes mercadorias $\left(\sum_{i} \lambda_{i} c_{i}^{j}\right)$. O segundo capta o dinamismo da composição da pauta exportadora $\left(\sum_{i} \lambda_{i} d_{i}\right)$. O terceiro e o quarto representam, respectivamente, a elasticidade-renda do comércio internacional $(t)$ e o crescimento da renda mundial $\left(y_{w}\right)$. O último termo representa a soma dos termos de interação, assim como na Equação (2) ${ }^{11}$.

O primeiro termo pode ser identificado como efeito competitividade. Ele é composto pela soma dos ganhos e perdas de parcela de mercado nas diferentes mercadorias $\left(c_{i}^{j}\right)$ e é ponderado pelo peso desse produto na pauta de exportações $\left(\lambda_{i}\right)$. Esse efeito será positivo sempre que os ganhos de market-share do país estejam concentrados em produtos que tenham uma participação na pauta maior do que aqueles onde houve perda de parcela de mercado. O segundo termo é chamado de efeito dinamismo da pauta e é uma soma ponderada dos efeitos dinamismo de cada produto $\left(d_{i}\right)$. Esse componente indica se as exportações do país são concentradas em produtos mais ou menos dinâmicos, i. é., produtos que ganharam ou perderam participação no comércio internacional. Por fim, além da soma dos termos de interação $(r)$, temos os efeitos elasticidade-renda do comércio $(t)$ e renda mundial $\left(y_{w}\right)$, que assinalam como e quanto o crescimento do comércio mundial impactou sobre o crescimento das exportações do país $\mathrm{j}^{12}$.

Podemos dizer que os dois primeiros componentes estão relacionados, em alguma medida, com a estrutura produtiva do país em questão e sua inserção externa. Esses dois efeitos indicam o quanto do crescimento das exportações é explicado pela própria estrutura dessa pauta, uma vez que são ponderados pelo peso inicial de cada produto. Além disso, como discutido na última seção, países com uma estrutura produtiva diversificada tem a capacidade de acompanhar os movimentos do comércio internacional, o que faria com que o segundo termo assumisse um valor sempre positivo.

O propósito dessa decomposição é explicitar quais determinantes estão por trás da elasticidade-renda das exportações da abordagem àla Thirlwall. Pela Equação (3) a elasticidaderenda das exportações vai ser maior que um sempre que a soma dos outros termos for positiva ${ }^{13}$. Assim, para que um país seja bem sucedido nas suas exportações, é necessário que ele ganhe mercado em produtos altamente dinâmicos. Isso faz com que o crescimento das suas exportações dependa menos de fatores externos e mais de sua própria estrutura produtiva ${ }^{14}$.

Os dados de comércio internacional são disponibilizados pelo Comtrade (http://comtrade.un.org/). Esse site fornece dados que podem ser desagregados tanto em nível de produtos quanto para os destinos dos fluxos de comércio. Já o PIB mundial é fornecido pelo Banco Mundial (http://www.worldbank.org/). Esses valores são dados em dólares correntes, sendo o PIB mundial a preços de mercado. Outro fator importante é que, devido a natureza dos dados, utilizaremos dados para as importações (ao invés das exportações) nos cálculos da decomposição. Ou seja, quando nos referimos às exportações brasileiras totais, por exemplo, o dado que estamos

\footnotetext{
${ }^{10}$ Neste trabalho optou-se por ponderar os componentes da decomposição pelos pesos iniciais a fim de analisar como a estrutura inicial da pauta exportadora afetou o crescimento das exportações. Entretanto, seria igualmente válido ponderar pelas participações finais ou por uma média entre os pesos iniciais e finais também.

${ }^{11}$ Vale mencionar que, embora esse termo tenha o mesmo significado nas Equações (2) e (3), seus valores não são os mesmos, uma vez que seus cálculos são distintos. Mantivemos a mesma notação para representar esse termo apenas para facilitar a exposição.

${ }^{12}$ Esses dois efeitos podem ser considerados como uma desagregação do crescimento do comércio mundial. Se considerarmos que $X^{W}=T Y^{W}$, com $T=\left(X^{W} / Y^{W}\right)$, então o crescimento das exportações mundiais vai ser composto pela elasticidade-renda do comércio e pelo crescimento da renda mundial: $x^{W}=t+y^{W}+t y^{W}$. Nesse caso, dado a ordem de grandeza dessas variáveis, podemos considerar que esses dois efeitos (excluindo-se o termo de interação) são uma boa aproximação para o crescimento do comércio mundial.

${ }^{13}$ Para ver isso de maneira mais clara, podemos rearranjar os termos da Equação (3) da seguinte maneira:

$$
\left[x^{j}-y_{w}\right]=\left[\sum_{i} \lambda_{i} c_{i}^{j}+\sum_{i} \lambda_{i} d_{i}+t+r\right] \text {. }
$$

${ }^{14}$ Para uma discussão mais extensa sobre a decomposição, ver Amaral (2016).
} 
utilizando são as importações mundiais provenientes do Brasil. É importante ter isso em mente sempre que a palavra exportação for utilizada na análise da decomposição na próxima seção.

A fim de facilitar a exposição e dado à infinidade de itens que compõem a pauta de exportação, optou-se por agrupar os dados para efetuar a decomposição. Para issofoi utilizada a classificação tecnológica apresentada por Lall (2000), que, segundo o próprio autor, é uma mistura de outras duas classificações: Pavitt (1984) e OECD (1994). A ideia de utilizar uma classificação tecnológica para agregar os dados da pauta de exportação serve para mostrar a especialização produtiva de um país, de acordo com o que foi discutido na seção anterior. A partir da classificação padrão de comércio internacional ${ }^{15}$ a três dígitos, os 239 itens da pauta foram agrupados em cinco categorias de acordo com sua sofisticação tecnológica: produtos primários (PP), manufaturas baseadas em recursos naturais (RB) e manufaturas de baixa (LT), média (MT) e alta tecnologia $(\mathrm{HT})^{16}$.

Quanto aos períodos, as decomposições serão realizadas para quatro intervalos. Esses subperíodos buscam retratar os diferentes momentos das exportações brasileiras. O primeiro vai de 1995 a 2003, quando as exportações brasileiras e mundiais cresciam mais lentamente. O segundo é marcado pela entrada da China na OMC, o ciclo de aumento no preço das commodities e o aumento expressivo no volume do comércio internacional e das exportações brasileiras, que cresceram aproximadamente $22 \%$ ao ano durante esse período, que vai de 2003 a 2008 . O terceiro período vai de 2008 a 2011. Nessa fase houve a eclosão da crise nos Estados Unidos, a desaceleração no comércio mundial e o aprofundamento das relações comerciais com a China, fazendo com que as exportações brasileiras dependessem cada vez mais dos produtos primários e manufaturas baseadas em recursos naturais. Por fim, o último período é marcado pelo declínio das exportações brasileiras em todas as categorias e vai de 2011 a 2014, que é o último ano para o qual o dado das exportações mundiais está completo e disponível.

\section{3) O crescimento das exportações brasileiras entre 1995 e 2014}

Entre 1995 e 2014 as exportações brasileiras cresceram mais que as exportações mundiais, tanto para o período como um todo como para a maioria dos subperíodos aqui considerados. No período agregado, as exportações mundiais cresceram pouco mais de $7 \%$ ao ano, enquanto as brasileiras cresceram a uma taxa anual de quase 9\%. Nos três primeiros subperíodos (1995-2003; 2003-2008 e 2008-2011), as exportações de produtos brasileiros cresceram sistematicamente acima da média mundial, sendo o período de maior dinamismo entre 2003 e 2008, onde as exportações brasileiras cresceram em média $22 \%$ ao ano. Apenas no último subperíodo (2011-2014) as

\footnotetext{
${ }^{15}$ Standard International Trade Classification (SITC, revisão 2).

${ }^{16}$ A classificação tecnológica de Lall (2000) agrupa os itens da pauta de exportação em cinco categorias. Os produtos primários (PP) são mercadorias que apresentam pouco ou nenhum processamento, sendo exportações praticamente in natura. Sua competitividade é, basicamente, dada pela dotação de recursos naturais. Como exemplos temos frutas frescas, arroz, soja, carvão, petróleo bruto, gás, etc. As manufaturas baseadas em recursos naturais (RB) são produtos simples e intensivos em trabalho, mas há também aqueles que utilizam tecnologias intensivas em capital ou escala, como o setor de alimentos processados ou o refino de petróleo. Essa categoria também abarca os produtos de origem agrícola e mineral (minérios), desde que tenham sofrido alguma transformação no processo produtivo. As manufaturas de baixa tecnologia (LT) se constituem numa classe de itens que utiliza tecnologia estável e muito bem difundida, presente nos bens de capital. O mercado para tais produtos possui pouco dinamismo, sendo sua elasticidade-renda baixa e com pouca diferenciação de produtos. A competição nesse mercado, na maioria dos casos, é dada via preços. Nessa categoria encontram-se os itens de vestuário, têxteis, calçados, brinquedos e artigos de plástico. O grupo das manufaturas de média tecnologia (MT) compreende a grande parte das tecnologias intensivas em escala, bens de capital e bens intermediários. É uma classe de produtos com elevadas barreiras à entrada e que adota tecnologias relativamente complexas, possuindo altos índices de $\mathrm{P} \& \mathrm{D}$, qualificação e longo período de aprendizagem. Como exemplo temos automóveis e autopeças, indústrias de processo que agrupam os produtos químicos e metais básicos, e produtos de engenharia como motores e máquinas industriais. Por fim, as manufaturas de alta tecnologia (HT) são produtos que empregam tecnologia avançada, sendo caracterizados por altos níveis de gastos em $\mathrm{P} \& \mathrm{D}$, com destaque para design de produto. Nessa categoria encontram-se produtos eletrônicos e de telecomunicação, e outros como, por exemplo, instrumentos de precisão, produtos da indústria farmacêutica e aeroespacial.
} 
exportações brasileiras não cresceram mais que as mundiais. Nessa fase as mercadorias brasileiras perderam espaço no mercado mundial e as exportações decresceram aproximadamente 5,5 pontos percentuais por ano.

O Gráfico 1 apresenta os resultados anualizados para as decomposições efetuadas. Dentre as fontes de crescimento das exportações, os efeitos associados ao crescimento do comércio internacional se mostraram, em média, os mais importantes para explicar o crescimento das exportações brasileiras. Nos dois primeiros períodos, a soma dos efeitos elasticidade-renda do comércio e renda mundial explicou, aproximadamente, $70 \%$ e $55 \%$ do crescimento das exportações. Nos dois últimos períodos, esses efeitos tiveram sinais contrários, uma vez que a elasticidade-renda do comércio internacional começou a cair. Mesmo assim, o efeito renda mundial continua se mostrando como o principal fator na explicação do crescimento das exportações brasileiras, representando $62 \%$ do crescimento das exportações entre 2008 e 2011 e atenuando a queda no último período, já que foi o único componente a contribuir positivamente nesses anos.

Gráfico 1 - Decomposição do crescimento das exportações brasileiras entre 1995 e 2014

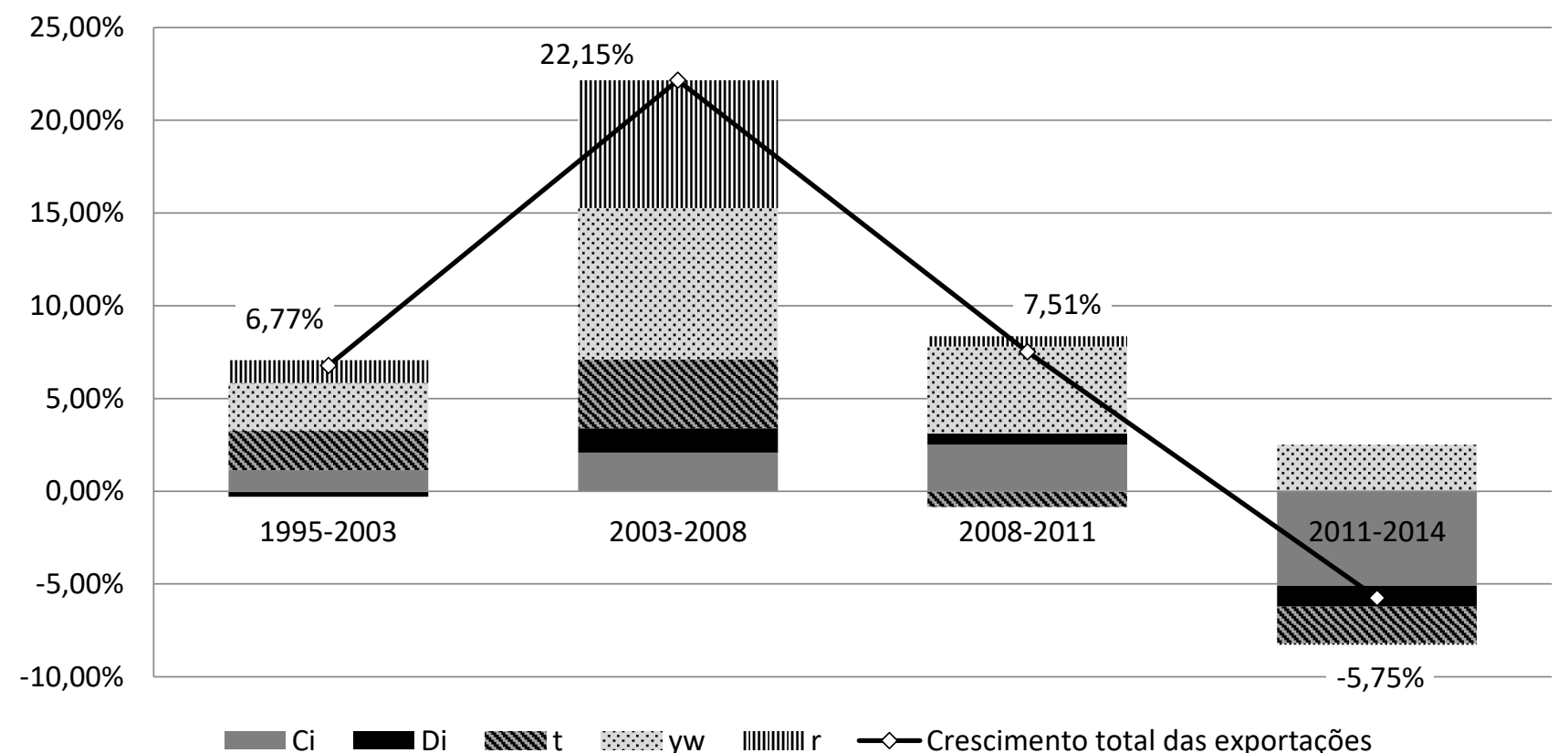

Legenda: (Ci) representa o efeito competitividade; (Di) o efeito dinamismo da pauta; (t) o efeito elasticidade-renda do comércio internacional; (yw) o efeito renda mundial e (r) é a soma dos termos de interação. Fonte: Elaboração própria a partir de dados do UN Comtrade.

Esses resultados estão em consonância com outros trabalhos aplicados para as exportações brasileiras utilizando o método CMS. Entre 1995 e 2004, Pinheiro e Bonelli (2007) demonstram que o efeito comércio mundial foi o maior indutor do crescimento das exportações brasileiras, sendo fonte de $77 \%$ da variação das exportações. O efeito competitividade foi modesto e contribuiu com $13 \%$ da variação total. Os efeitos composição da pauta e distribuição de destinos foram muito pequenos, embora tenham sido positivos. Pereira e Souza (2011) mostram que o efeito comércio mundial foi o maior indutor do aumento das exportações brasileiras tanto no período que vai de 1999 a 2009, como para alguns subperíodos considerados. No agregado, o efeito competitividade também foi importante. Já para os subperíodos, esse efeito vai perdendo importância com o passar do tempo. Os efeitos composição da pauta e distribuição de destinos foram modestos, contribuindo com menos de $10 \%$ para a variação das exportações entre 1999 e 2009. Lima, Lélis e Cunha (2015) apresentam um resultado parecido para o período entre 2000 e 2011. Os autores argumentam que o efeito positivo da composição da pauta está relacionado com uma maior concentração das exportações em produtos primários, que foram os que apresentaram maior dinamismo no comércio mundial. 
A contribuição dos componentes relacionados ao dinamismo da pauta e ao crescimento da competitividade tiveram efeitos reduzidos sobre o crescimento das exportações, embora suas contribuições tenham sido, na maioria das vezes, positiva. Somente no último período, quando as exportações brasileiras decresceram a taxa de $5,75 \%$ ao ano, é que esses componentes adquirem peso maior. Ou seja, a expansão das exportações brasileiras nos três primeiros períodos esteve muito mais relacionada com a evolução do comércio internacional do que com o perfil de especialização comercial ou com ganhos de competitividade. Entretanto, no último período vemos que esses efeitos adquirem um peso muito maior na explicação do decrescimento das exportações, o que sugere que, nessa fase, houve um enfraquecimento da competitividade dos produtos brasileiros, uma vez que a soma desses efeitos foi maior (em módulo) que o próprio decrescimento das exportações.

Esse enfraquecimento pode ser ilustrado pela evolução do Índice de Qualidade Schumpeteriano das Exportações $\left(Q_{X}^{S}\right)$ desenvolvido por Libânio (2012). O índice é calculado a partir da composição da pauta e utiliza a mesma classificação tecnológica adotada neste trabalho. A qualidade das exportações é medida em termos tecnológicos e quanto maior forem as exportações de manufaturas de média e alta tecnologia frente as demais, maior será esse índice:

$$
Q_{X}^{S}=\frac{(M T+H T)-(P P+R B+L T)}{\text { exportações totais }}
$$

onde PP representa as exportações de produtos primários, RB as de manufaturas baseadas em recursos naturais e LT, MT e HT representam, respectivamente, as exportações de manufaturas de baixa, média e alta tecnologia. Esse indicador capta o tipo de especialização tecnológica e a inserção externa do país em questão. Ele varia entre (-1) e (+1), sendo que o valor máximo indicaria que essa economia tem todas as suas exportações concentradas em manufaturas de média e alta tecnologia. O gráfico a seguir apresenta o índice de qualidade das exportações para a economia brasileira nos anos analisados.

Gráfico 2 - Índice de Qualidade das Exportações brasileiras entre 1995 e 2014

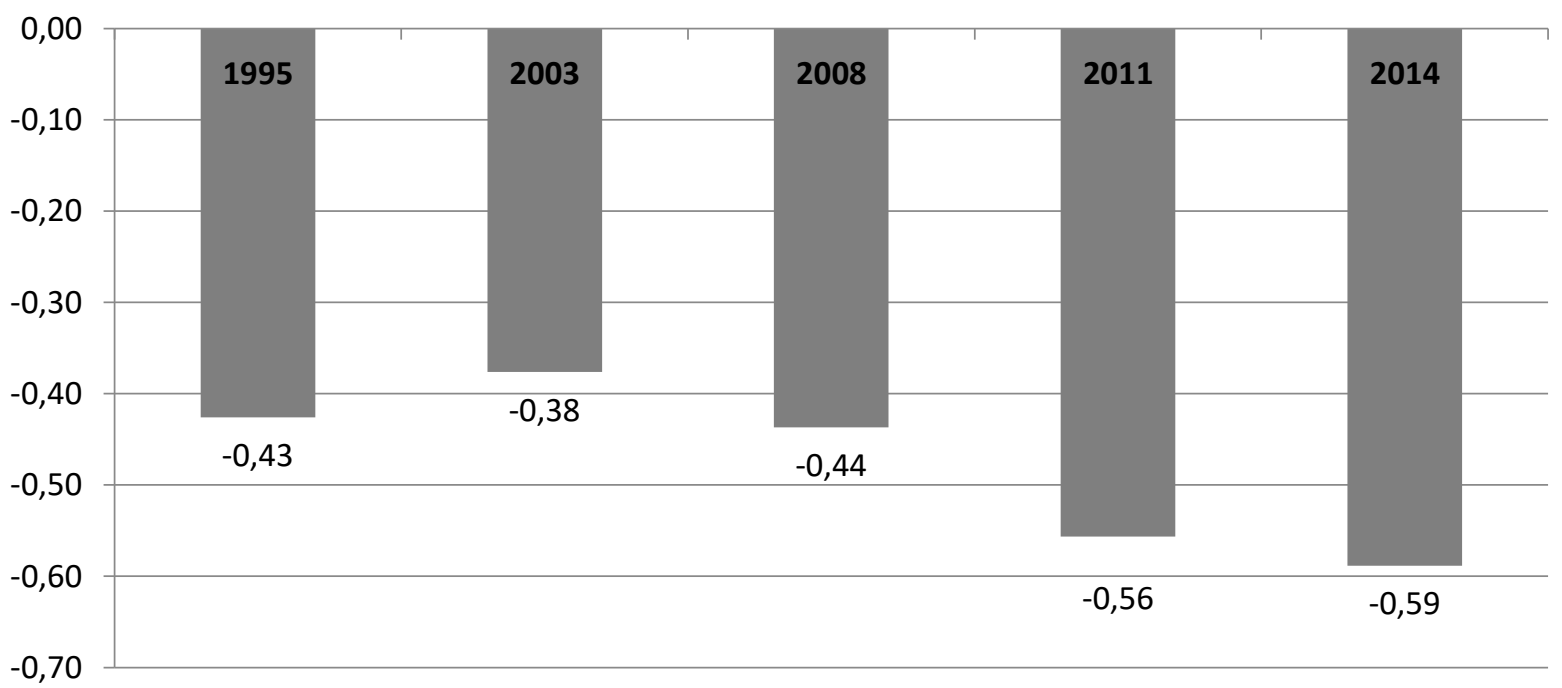

Fonte: Elaboração própria a partir de dados do Comtrade.

Percebe-se que o índice nunca foi positivo, ou seja, as exportações de mercadorias com menor sofisticação tecnológica (PP, RB e LT) sempre foram maiores que as exportações de média e alta tecnologia. Entretanto, a partir de 2003 esse índice começa a decair continuamente, atingindo seu menor valor em 2014. Dito em outras palavras, as exportações de produtos primários e 
manufaturas baseadas em recursos naturais e de baixa tecnologia, juntas, ganharam peso na pauta de exportações ${ }^{17}$.

Entretanto, esse movimento não está circunscrito às exportações brasileiras, sendo uma tendência recente do comércio mundial (TORRACA ET AL., 2015). Com o aumento no preço das commodities e o crescente apetite chinês por essas mercadorias, as exportações menos sofisticadas (PP e RB) ganharam participação nas exportações mundiais também. O Gráfico 2 ilustra o crescimento anual das exportações brasileiras e mundiais entre 1995 e 2014 e mostra esse movimento.

Gráfico 3 - Taxa de crescimento anual das exportações brasileiras e mundiais entre 1995 e 2014

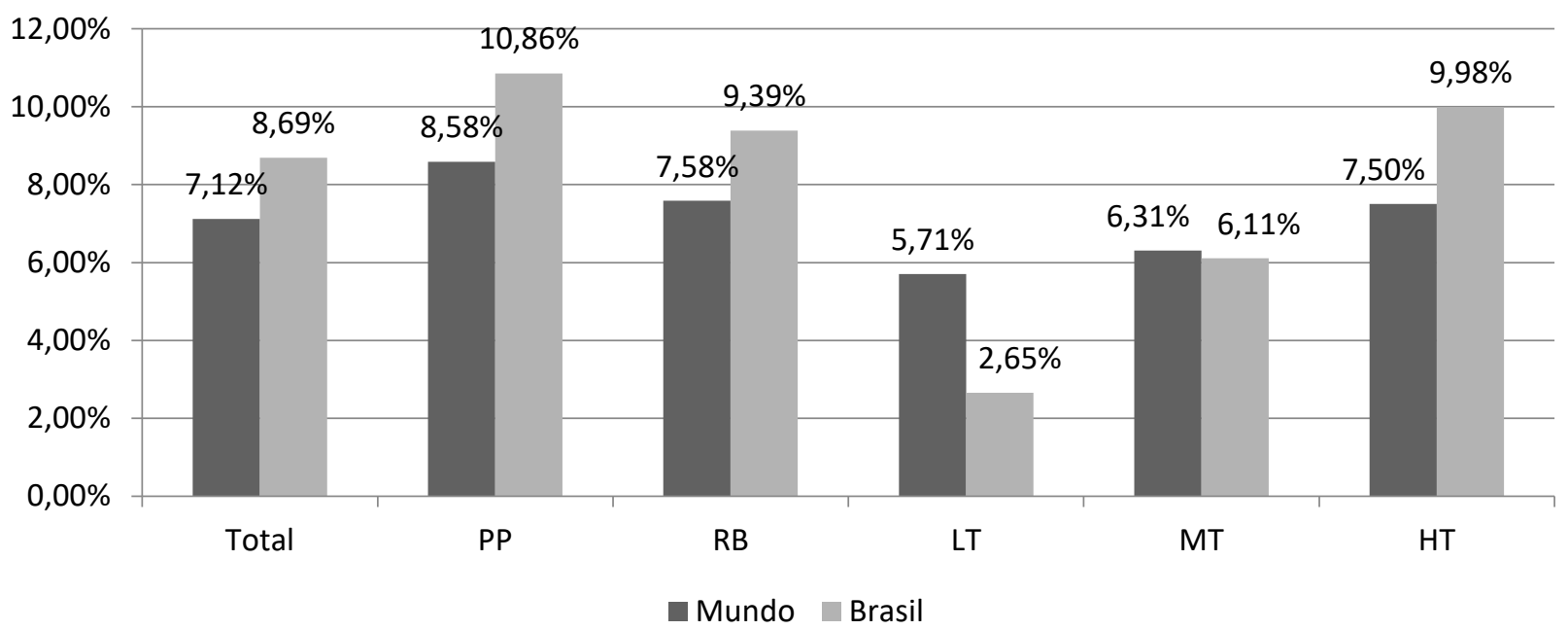

Legenda: (PP) representa as exportações de produtos primários; (RB) as de manufaturas baseadas em recursos naturais; (LT) as manufaturas de baixa tecnologia; (MT) as manufaturas de média tecnologia e (HT) as manufaturas de alta tecnologia. Fonte: Elaboração própria a partir de dados da Comtrade.

Conforme já foi apontado, nesse período as exportações brasileiras cresceram mais que as mundiais. Entretanto, pelo Gráfico 3 vemos que esse crescimento superior esteve concentrado em três categorias: produtos primários, manufaturas baseadas em recursos naturais e de alta tecnologia. Todavia, devido à participação reduzida que as exportações de alta tecnologia têm ${ }^{18}$, sua contribuição foi muito pequena para o crescimento total das exportações brasileiras nesse período.

$\mathrm{O}$ aumento no preço das commodities, que estão concentradas nas categorias PP e RB, somado à crescente participação chinesa no mercado internacional, fez com que a participação desses produtos nas exportações mundiais aumentasse. Em 1995 as exportações dessas duas categorias representavam $31 \%$ das exportações mundiais. Até 2014 esses produtos aumentaram sua participação para $37 \%$ do total, enquanto a participação das manufaturas foi reduzida. As categorias mais afetadas foram as manufaturas de baixa e média tecnologia que, juntas, perderam oito por cento em suas participações nas exportações mundiais.

No Brasil esse movimento na direção mercadorias menos elaboradas foi mais intenso do que o experimentado pelo mundo. As exportações de produtos primários e manufaturas baseadas em recursos naturais cresceram aproximadamente $10 \%$ ao ano no período analisado. Em 1995, essas categorias representavam $26 \%$ e $32 \%$ do total exportado. Já em 2014, essas duas categorias somadas foram responsáveis por $75 \%$ das exportações brasileiras (38\% e 37\%, respectivamente).

Comparando a composição das exportações brasileiras e mundiais, vemos que a estrutura das exportações brasileiras já era muito diferente da mundial em 1995. As categorias PP e RB possuem peso muito maior nas exportações brasileiras em todos os períodos, se comparadas à

\footnotetext{
${ }^{17}$ Os ganhos de participação dos produtos PP e RB na pauta de exportações mais que compensou a perda de peso das manufaturas de baixa tecnologia em todos os períodos.

${ }^{18} \mathrm{Em} 1995$ as exportações de manufaturas de alta tecnologia representavam 3,25\% do total das exportações brasileiras. Em 2014 essa participação subiu para 4,15\%.
} 
composição das exportações mundiais. Ou seja, em 1995 o Brasil já era especializado na produção dessas mercadorias e, ao longo do tempo, essa especialização se aprofundou.

Figura 1 - Composição das exportações mundiais e brasileiras em 1995 e 2014
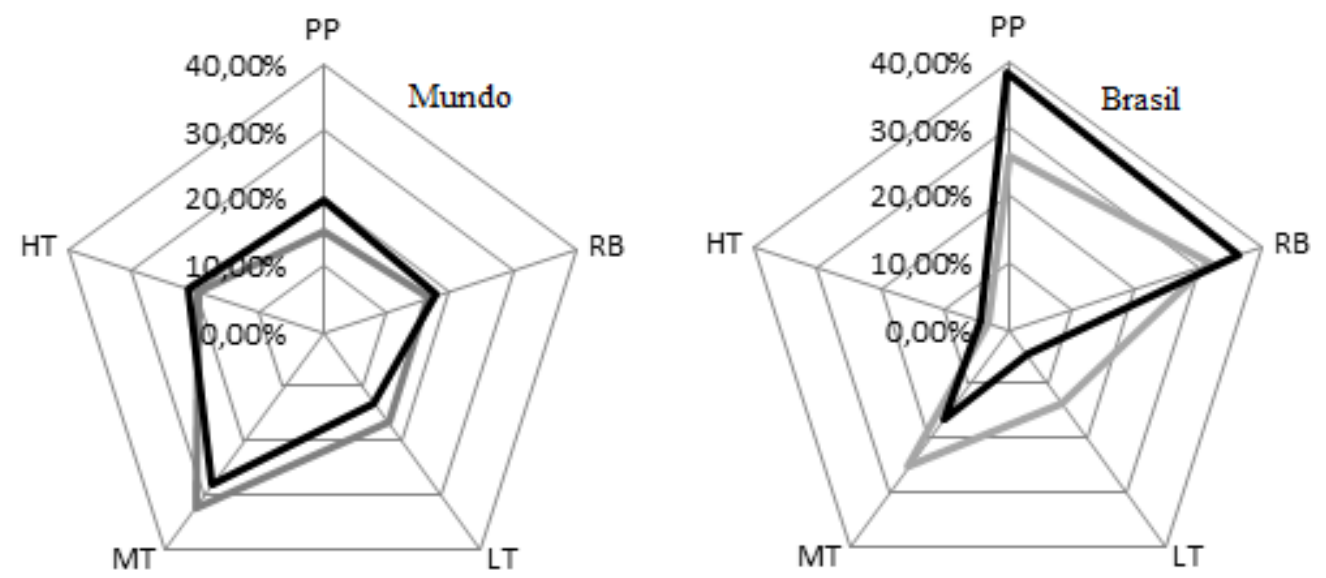

$1995-2014$

Legenda: (PP) representa as exportações de produtos primários; (RB) as de manufaturas baseadas em recursos naturais; (LT) as manufaturas de baixa tecnologia; (MT) as manufaturas de média tecnologia e (HT) as manufaturas de alta tecnologia. Fonte: Elaboração própria a partir de dados da Comtrade.

Esse movimento é evidenciado pela evolução do Índice de Vantagens Comparativas Reveladas (IVCR) de Balassa (1965), que indica a especialização produtiva de um país em determinado produto. O índice é calculado por:

$$
I V C R=\frac{\left(X_{i}^{j} / X^{j}\right)}{\left(X_{i}^{W} / X^{W}\right)}
$$

onde $X_{i}^{j}$ representa as exportações do produto i pelo país j, $X^{j}$ representa as exportações totais desse país e $X_{i}^{W}$ e $X^{W}$ representam as exportações mundiais do produto i e as exportações mundiais totais, respectivamente. Se o índice for igual ou maior que um, o país em questão possui vantagem comparativa revelada na exportação desse bem, ou seja, é especializado nessa produção. Quando o índice é menor que um então esse país possui desvantagem comparativa na produção desse bem. $\mathrm{O}$ Gráfico 4 a seguir apresenta os valores desse índice para as exportações brasileiras agrupadas nas cinco categorias analisadas em 1995 e 2014, a fim de demonstrar que o país já possuía vantagens comparativas nas categorias PP e RB e que essa especialização se aprofunda ao longo do período analisado.

As vantagens comparativas do Brasil na produção de mercadorias de baixa e média tecnologia caíram no período analisado, enquanto as outras três aumentaram. A especialização na produção dos produtos primários e manufaturas baseadas em recursos naturais era alta em 1995 e se aprofundou, assumindo um valor próximo de dois no fim do período para ambas as categorias. Isto indica que o peso de cada uma dessas categorias na pauta de exportações brasileira é duas vezes maior que suas respectivas participações nas exportações mundiais.

Dessa forma, não seria equivocado afirmar que as alterações na composição da demanda mundial favoreceram as exportações brasileiras na medida em que a maioria das categorias que ganharam participação no comércio internacional foram aquelas nas quais o Brasil já possuía bom desempenho exportador. Ou seja, a demanda internacional se movimentou na direção de produtos em que o Brasil já possuía vantagens comparativas em sua produção. Isto fez com que o país aumentasse sua parcela de mercado justamente nas categorias dinâmicas, sendo fortemente 
beneficiado pelas alterações nas estruturas de demanda mundial e dos preços relativos entre 1995 e 2014.

Gráfico 4 - Índice de Vantagens Comparativas Reveladas (IVCR) das exportações brasileiras em 1995 e 2014

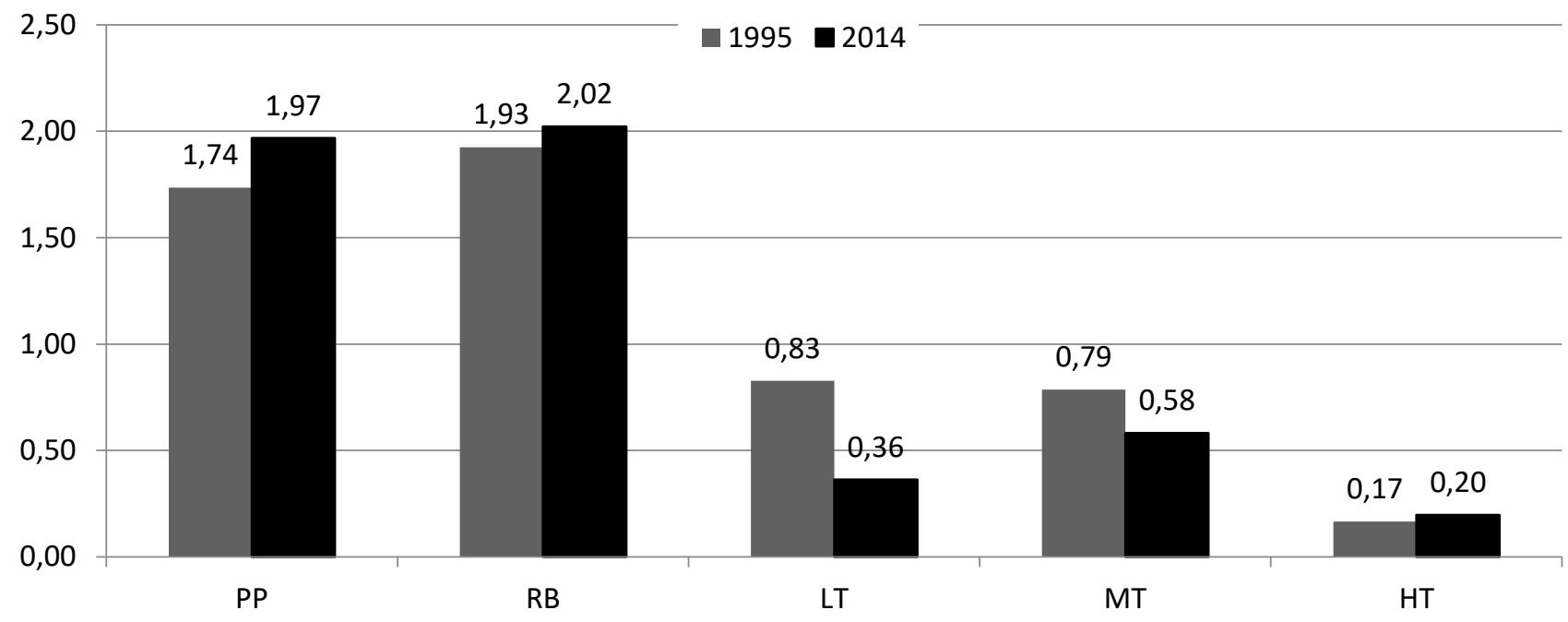

Legenda: (PP) representa as exportações de produtos primários; (RB) as de manufaturas baseadas em recursos naturais; (LT) as manufaturas de baixa tecnologia; (MT) as manufaturas de média tecnologia e (HT) as manufaturas de alta tecnologia. Fonte: Elaboração própria a partir de dados da Comtrade.

Podemos complementar essa visão de duas maneiras adicionais. A primeira é através do Índice de Adaptabilidade das Exportações $\left(A_{j}\right)$ utilizado em Palma (2009). O índice apresenta a capacidade que um país possui de reagir a mudanças na composição da demanda mundial. $\mathrm{O}$ índice $A_{j}$ é construído a partir da razão entre o market-share do país j (no mercado mundial) nos produtos dinâmicos, isto é, aqueles que ganharam participação no comércio internacional, e dos não dinâmicos (tudo ponderado pela parcela de mercado total do país):

$$
\begin{gathered}
A_{j}=\frac{\sum_{i} a_{i}^{d}}{\sum_{i} a_{i}^{n d}} \\
a_{i}=\frac{\left(X_{i}^{j} / X_{i}^{W}\right)}{\left(X^{j} / X^{W}\right)}
\end{gathered}
$$

onde $a_{i}$ é igual ao market-share no mercado mundial do país j no produto i dividido pelo marketshare total do país nas exportações mundiais. Os sobrescritos $d$ e $n d$ indicam os produtos dinâmicos e não dinâmicos, respectivamente. Quando o valor do índice é igual a um, podemos dizer que a composição das exportações do país j é exatamente igual à composição das exportações mundiais, indicando que a estrutura das exportações do país em termos de dinamismo é idêntica à estrutura mundial. Um alto valor para esse índice sugere que o país foi capaz de acompanhar as alterações na demanda mundial e adaptar sua pauta de exportações na direção dessas mudanças.

O Índice de Adaptabilidade das Exportações para as exportações brasileiras, utilizando a classificação tecnológica de Lall (2000) entre 1995 e 2014, tem valor de 4,44. Esse valor é elevado e indica que a soma das parcelas de mercado do Brasil nas categorias que ganharam peso no comércio internacional (PP, RB e HT) nesse período foi mais de quatro vezes maior do que o market-share das categorias que tiveram sua participação reduzida (LT e MT). Ou seja, esse índice indica que o crescimento das exportações brasileiras foi afetado positivamente pelas alterações na estrutura e na composição das exportações mundiais entre 1995 e 2014.

Outra forma de visualizar esse processo é a análise combinada dos efeitos competitividade e dinamismo do produto para entender a relação entre os ganhos de market-share de um país e as 
alterações na composição do comércio internacional. Essa análise remonta a Mandeng (1991), embora a adotada aqui seja muito mais simplificada. $\mathrm{O}$ que nos interessa é entender se o país ganhou ou perdeu parcela de mercado em produtos que ganharam ou perderam participação no comércio internacional, considerando-se as cinco categorias presentes em Lall (2000). Na Figura 2 a seguir, o eixo das abscissas representa o crescimento das parcelas de mercado brasileiras nas diferentes categorias tecnológicas entre 1995 e 2014. No eixo das ordenadas está representado o crescimento da participação relativa no comércio internacional dessas mesmas categorias para o mesmo período. Ou seja, estamos analisando conjuntamente os efeitos competitividade $\left(c_{i}^{j}\right) \mathrm{e}$ dinamismo do produto $\left(d_{i}\right)$.

Figura 2 - Crescimento da participação no comércio internacional (eixo Y) e crescimento do market-share brasileiro (eixo X)

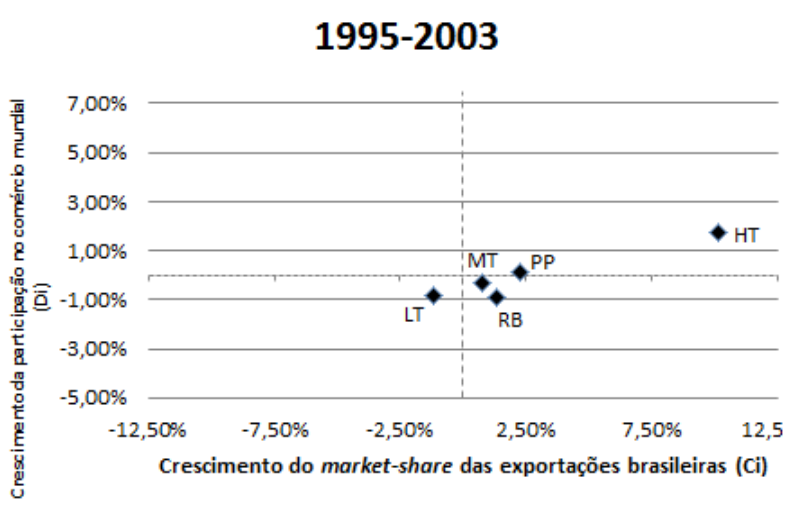

2008-2011

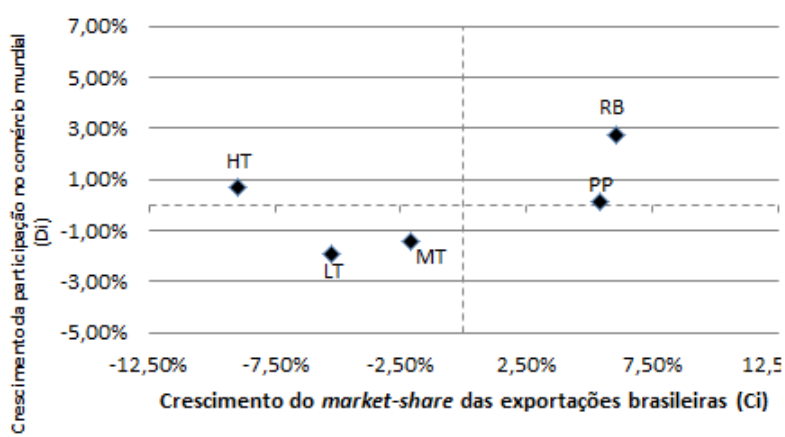

2003-2008

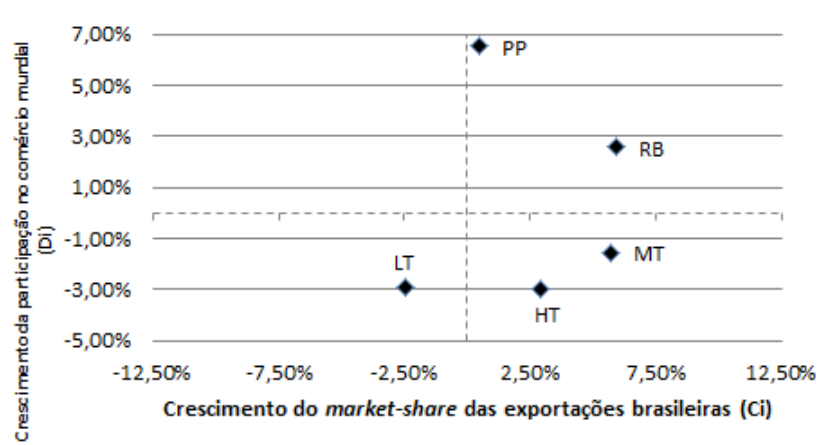

2011-2014

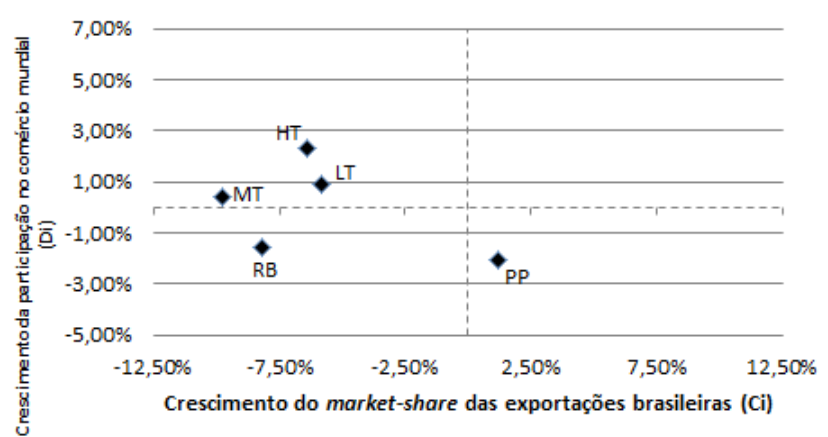

Legenda: (PP) representa as exportações de produtos primários; (RB) as de manufaturas baseadas em recursos naturais; (LT) as manufaturas de baixa tecnologia; (MT) as manufaturas de média tecnologia e (HT) as manufaturas de alta tecnologia. Fonte: Elaboração própria a partir de dados da Comtrade.

Dessa análise, vemos que, na maioria dos períodos, as exportações brasileiras ganharam maior parcela de mercado justamente nas categorias que aumentaram sua participação no comércio internacional (PP e RB). Isso corrobora o argumento de que as mudanças ocorridas na composição do comércio mundial em direção a mercadorias menos sofisticadas teve um efeito direto sobre as exportações brasileiras, que seguiram ganhando competitividade com o aumento da demanda mundial por esse tipo de produto. Isso poderia explicar uma parte da especialização regressiva da pauta de exportações brasileira.

Outro fato que merece destaque é o de que as exportações brasileiras lograram aumentar seu market-share também nas manufaturas mais sofisticadas (MT e HT) até 2008, ainda que essas categorias não estivessem ganhando participação no comércio mundial. Entretanto, a partir da crise de 2008, o país começou a perder competitividade nessas categorias. Nos outros períodos, por mais que os ganhos de competitividade fossem maiores nos produtos mais básicos, o país não estava perdendo competitividade nos produtos MT e HT e, inclusive, aumentou marginalmente sua parcela de mercado nesses produtos. Com a eclosão da crise, o crescimento das exportações brasileiras passou a depender muito mais dos produtos primários e manufaturas baseadas em recursos naturais, contribuindo também para a especialização regressiva. 
A configuração de todos esses fatores é preocupante, uma vez que no último período a única categoria em que o país obteve aumento de competitividade foi a que mais perdeu espaço no comércio mundial (PP). Além disso, a categoria onde as exportações brasileiras eram mais competitivas (RB) também perdeu participação. Isto indica que o comércio mundial está caminhando em direção a mercadorias em que o país não é capaz ou não possui vantagens para produzir. Podemos demonstrar isto pelo Índice de Adaptabilidade das Exportações já utilizado nessa seção. Para o período entre 2011 e 2014, o índice assumiu seu menor valor. Enquanto o valor do índice foi de 2,28 e 3,88 para os períodos entre 2003-2008 e 2008-2011, respectivamente, para 2011-2014 o índice foi de 0,29. Isto indica que o market-share dos produtos não dinâmicos na pauta brasileira é quase três vezes maior que o dos dinâmicos no período.

Dessa forma, o bom desempenho das exportações brasileiras no período como um todo está relacionado com o aumento dos preços e da demanda mundial por mercadorias em que o Brasil já era especializado. Ou seja, uma vez que o país já possuía vantagens comparativas reveladas na produção desses bens, a mudança na composição da demanda mundial acabou por ampliar as exportações brasileiras e por fazer com que o país aumentasse seu market-share nos produtos em que já era especializado. Isto intensificou a participação relativa de produtos menos sofisticados na pauta brasileira e aprofundou a especialização comercial do país nas exportações desse tipo de mercadorias, que em 2014 representaram três quartos do total das exportações.

\section{Considerações finais}

Entre 1995 e 2014, as exportações brasileiras experimentaram uma fase de rápido crescimento, alcançando taxas de crescimento superiores às mundiais. Durante esse período, houve uma alteração na composição da pauta, com os produtos básicos ganhando peso nas exportações totais e se tornando a principal categoria exportada pelo país. Essa crescente dependência da pauta exportadora às commodities, denominada na literatura como reprimarização da pauta exportadora, tem como contrapartida a queda na participação das exportações das manufaturas não baseadas em recursos naturais no total exportado. Essa reprimarização não foi um fenômeno ocorrido apenas no Brasil. Com o aumento no preço das commodities e o crescente apetite chinês por essas mercadorias as exportações desses produtos ganharam participação nas exportações mundiais também. Entretanto, mesmo sendo uma tendência mundial, no Brasil esse movimento na direção de mercadorias menos elaboradas e intensivas em recursos naturais foi mais intenso do que o observado no mundo.

Neste trabalho, analisou-se os determinantes do crescimento das exportações brasileiras entre 1995 e 2014, identificando as fontes do crescimento recente das exportações. Para isso, foi proposto um método para decompor o crescimento das exportações de um país em quatro componentes. O primeiro está associado ao crescimento da competitividade do país nos diferentes produtos. O segundo capta o dinamismo da composição da pauta e indica se o país tem sua pauta exportadora concentrada em produtos que ganharam ou perderam participação no comércio mundial. O terceiro representa a elasticidade-renda do comércio internacional e o quarto capta os efeitos do crescimento da renda mundial.

Os resultados apontaram que, dentre as fontes de crescimento das exportações, os efeitos associados ao crescimento do comércio internacional (elasticidade-renda do comércio e renda mundial) são, em média, os mais importantes para explicar o crescimento das exportações brasileiras. Esse resultado é coerente com outros estudos empíricos que mostram a importância do comércio internacional como determinante do crescimento das exportações brasileiras.

A contribuição dos componentes relacionados à composição da pauta e ao crescimento da competitividade tiveram efeitos reduzidos sobre o crescimento das exportações, embora suas contribuições tenham sido, na maioria das vezes, positivas. Ou seja, a expansão das exportações brasileiras nos três primeiros períodos esteve muito mais relacionada com a evolução do comércio internacional do que com ganhos de competitividade. 
O bom desempenho das exportações brasileiras no período como um todo está relacionado com o aumento dos preços e da demanda mundial por mercadorias em que o Brasil já era especializado. Entre 1995 e 2014, o Índice de Adaptabilidade das Exportações assume um valor elevado, indicando que a soma das parcelas de mercado do Brasil nas categorias que ganharam peso no comércio internacional (PP, RB e HT) nesse período foi muito maior do que o market-share das categorias que tiveram sua participação reduzida (LT e MT). Como o país já possuía vantagens comparativas reveladas na produção desses bens (PP e RB), a mudança na composição da demanda mundial acabou por ampliar as exportações brasileiras e por fazer com que o país aumentasse seu market-share nos produtos que já era especializado. Isto intensificou a participação relativa de produtos primários e manufaturas baseadas em recursos naturais na pauta e aprofundou a especialização comercial do país nas exportações desse tipo de mercadorias.

Com a eclosão da crise, o crescimento das exportações brasileiras passou a depender muito mais dos produtos primários e manufaturas baseadas em recursos naturais. Diferentemente dos outros períodos, o país não perdeu competitividade apenas nas manufaturas de baixa tecnologia: as exportações brasileiras perderam parcela de mercado nas duas categorias mais sofisticadas (MT e HT), enquanto ganharam nos produtos mais básicos (PP e RB). Tudo isso contribui diretamente para o processo de especialização regressiva da pauta de exportações brasileira, que se intensificou a partir de 2011, com a perda de competitividade mais acentuada em quase todas as categorias.

A configuração de todos esses fatores é preocupante, uma vez que os resultados obtidos apontam que o comércio mundial está caminhando em direção a mercadorias que o país não é capaz ou não possui vantagens para produzir, como evidenciado pelo Índice de Adaptabilidade das Exportações. Com o preço das commodities em um nível mais baixo e a perda de competitividade dos produtos industriais, as exportações brasileiras possivelmente não apresentarão o dinamismo de períodos recentes e, nesse caso, a restrição externa poderá voltar a ser um entrave para o crescimento brasileiro. 


\section{Bibliografia}

AMARAL, F. (2016). Comércio internacional, especialização produtiva e competitividade: uma decomposição para o crescimento das exportações brasileiras entre 1995 e 2014. Dissertação de mestrado não publicada, Rio de Janeiro, Instituto de Economia, UFRJ (mimeo).

BALASSA, B. (1965). Trade liberalisation and revealed comparative advantage. Washington: World Bank.

BHERING, G.; SERRANO, F. (2014). A Restrição Externa e a "Lei de Thirlwall" com Endividamento Externo. Anais do XLII Encontro Nacional de Economia, 2014.

CASTILHO, M. (2010). A inserção do Brasil em um mundo fragmentado: uma análise da estrutura de comércio exterior brasileiro. In: Luciana Acioly e Marcos Antonio Macedo Cintra. (Org.). Inserção Internacional Brasileira: temas de economia internacional. 1 ed. Brasília: IPEA, v. 2, p. 369-396.

COSTA, K.; CASTILHO, M.; TORRACCA, J. (2016). Desempenho e perspectivas das exportações brasileiras de produtos manufaturados - perfil e perda de mercado do Brasil na América Latina. XLIV Encontro Nacional de Economia.

CIMOLI, M. \& CORREA, N. (2002) Trade Openness and Technology Gaps in Latin America: A Low-Growth Trap. In: Ocampo, J. A. (ed.) Beyond Reforms: Structural Dynamics and Macroeconomic Vulnerability. Washington: United Nations Economic Commission for Latin America and the Caribbean.

CIMOLI, M.; PORCILE, G.; ROVIRA, S. (2010). Structural change and the BOP-constraint: why did Latin America fail to converge? Cambridge Journal of Economics, 34(2) pp. 389-411.

COUTINHO, L. (1997). A especialização regressiva: um balanço do desempenho industrial pósestabilização. IN VELLOSO, J.P.R. (org.), Brasil: desafios de um país em transformação, Editora José Olympio.

DOSI, G.; PAVITT, K.; SOETE, L. (1990). Technology and trade: an overview of the literature. In: DOSI, G. et al. (Org.). The economics of technical change and international trade. Hertforshire: Harvester Wheatsheaf.

FAGERBERG, J.; SHROLEC, M. e KNELL, M. (2007) The Competitiveness of Nations: Why Some Countries Prosper While Others Fall Behind. World Development, 35(10), 1595-1620.

FREITAS, F. e DWECK, E. (2013). The Pattern of Economic Growth of the Brazilian Economy 1970-2005: A Demand-Led Growth Perspective. In: LEVRERO, E. et al. (eds.) Sraffa and The Reconstruction of Economic Theory: Volume Two: Aggregate Demand, Policy Analysis and Growth. Palgrave Macmillian.

JAYME JR., F. G.; RESENDE, M. F. C. (2009). Crescimento econômico e restrição externa: teoria e a experiência brasileira. In: Crescimento econômico: setor externo e inflação. Rio de Janeiro: Livro IPEA cap. 1, p. 9-36.

KALDOR, N. (1978[1971]). "Conflicts in National Economic Objectives", in Kaldor, N., Further Essays on Economic Theory, N. York: Holmes \& Meier

LALL, S. (2000). The technological structure and performance of developing country manufactured exports, 1985-98. Oxford Development Studies, vol. 28, nº 3.

LEAMER, E.; STERN, R. (1970). Constant-market-share analysis of export growth. In: LEAMER \& STERN (Org.). Quantitative international economics. Boston: Allyn and Bacon. Cap. 7, p. 171183. 
LIBÂNIO, G. (2012). O comércio Brasil-China em uma perspectiva regional: análise $e$ implicações para o desenvolvimento. Rio de Janeiro: BNDES/ANPEC, 33 p. (Texto para discussão, 42).

LIMA, LÉLIS E CUNHA (2015) Comércio internacional e competitividade do Brasil: um estudo comparativo utilizando a metodologia Constant-Market-Share para o período 20002011, Econ. e soc. vol. 24, n.2.

MANDENG, O. S. (1991). Competitividad internacional y especialización. Revista de la Cepal, Santiago, n. 45, 1991.

McCOMBIE, J. S. L. \& ROBERTS, M. (2002) The Role of the Balance of Payments in Economic Growth. In: Setterfield, M. (ed.) Demand-Led Growth: challenging the supply side vision of the long run, Aldershot: Edward Elgar.

McCOMBIE, J. S. L. \&THIRLWALL, A. P. (1994) Economic Growth and the Balance of Payments Constraint, Londres: Macmillan.

MEDEIROS, C. A. \& SERRANO, F. (1999). Padrões monetários internacionais e crescimento. In: FIORI, J. L. (Org.). Estados e moedas no desenvolvimento das nações. Petrópolis: Vozes.

MEDEIROS, C. A. \& SERRANO, F. (2001). Inserção Externa, Exportações e Crescimento no Brasil. in: Fiori, J. L.; Medeiros, C. (Org.). Polarização Mundial e Crescimento. Petrópolis, Vozes.

OCAMPO, J. A. (2009). Growth and policy in developing countries: A Structuralist Approach. Nova York: Columbia University Press.

PALMA, J. G. (2009). Flying geese and waddling ducks: the different capabilities of East Asia and Latin America to "demand-adapt" and "supply-upgrade" their export productive capacity. In: M. Cimoli, G. Dosi and J. Stiglitz (eds.), The Political Economy of Capabilities Accumulation: the Past and Future of Policies for Industrial Development, Oxford University Press.

PAVITT, K. (1984). Patterns of technical change: towards a taxonomy and a theory. Research Policy, 13, 343-374.

PEREIRA, L. V.; SOUZA, A. L. S. de (2011). Exportações brasileiras na primeira década do século XXI: desempenho e fontes de crescimento. In: BONELLI, R. (Org.). A agenda de competitividade do Brasil. Instituto brasileiro de Economia. Rio de Janeiro: Editora FGV. Cap 11, p. 323-378.

PINHEIRO, A. C.; BONELLI, R. (2007). Comparative advantage or economic policy? Stylized facts and reflections on Brazil's insertion in the world economy - 1994-2005. Rio de Janeiro: Ipea, abr. 2007. (Texto para Discussão, n. 1275a).

PREBISCH, R. (1949). O desenvolvimento econômico na América Latina e alguns de seus principais problemas. In: GURRIERI, A. (Org.). Manifesto Latino-Americano e outros ensaios, Contraponto Editora, Rio de Janeiro.

RICHARDSON, J. D. (1971a). Some Sensitivity Tests for a "Constant-Market-Shares" Analysis of Export Growth. The Review of Economics and Statistics, Statistics, Vol. 53, No. 3 (Aug., 1971), pp. 300-304.

RICHARDSON, J. D. (1971b). Constant-market-shares-analysis of export growth. Journal of International Economics, Wisconsin, I, p. 227-239, 1971.

ROMERO, J. P.; SILVEIRA, F.; BRITTO, G. (2011). Structural change, National Innovation System and balance-of-payments constraint: a theoretical and empirical analysis of the brazilian case. Belo Horizonte: UFMG/CEDEPLAR, 32 p. (Texto para discussão; 440).

THIRLWALL, A. P. (1979). The balance of payments constraint as an explanation of international growth rate differences. In: McCombie, J.S.L.; Thirlwall, A.P. (2004). Essays on Balance of Payments Constrained Growth: Theory and Evidence. Routledge, Londres. 
THIRLWALL, A. (2005) A Natureza do Crescimento Econômico: um referencial alternativo para compreender o desempenho das nações, Brasília: IPEA. 